\title{
Familial Paraganglioma
}

National Cancer Institute

\section{Source}

National Cancer Institute. Familial Paraganglioma. NCI Thesaurus. Code C5329.

A familial neoplasm arising from paragang lia. The majority of cases (up to 80\%) are multifocal. It is caused by mutations in SDHB, SDHC, and SDHD genes. 